\title{
16. Minimay: One of 6,000 Weatherboard Schools
}

\author{
Australian Cultural History 7 (1988), pp. 5-17.
}

At the western end of the Grampians in Victoria the slopes push the streams in many directions. The creeks feeding the Wimmera River flow north, Mosquito Creek drains intermittently into the lagoons of southeastern South Australia, and the Glenelg curves south. It alone has its secure route to the Southern Ocean. The watershed northwest in wet years spreads through chains of creeks, swamps and lakes: Lake Winter, Lake Charlegrark, Booroopki Swamp and Warm Swamp; and Neuarpurr, Minimay and Tooroot Swamps. The fall on the land is so slight that often it is only the height of the water itself that forces the frontier of the flood further north. Swamps and creeks disappear at the southern edge of the Little Desert.

In the early 1880s selectors were taking up 320-acre blocks in the Booroopki and Minimay area. They struggled to clear land so they could scratch in a few acres of hand-scattered crop; they extended their brush and dog-leg fences, and converted bough sheds into mud-plastered stringybark huts; and they went without to pay their debts to the storekeepers and the Lands Department. Most selectors were determined self-improvers. And they wanted schools for their children. As a group the selectors petitioned, and separately they wrote to their MPs and the Minister for Public Instruction. On 1 May 1882 Andrew McLaughlin listed nine Minimay families with a total of twenty-five children of school age. Chas Harris wrote five months later:

As the selectors of the parish of Minimay is badly situated with regards of a School We do humbly ask of you to try and see if we can get a school erected here for it is much needed there is between 20 or 30 children here growing up in ignorance.

William McBean, a former teacher, said he was ready to take time from working his selection to open a school, but he was too poor to do so without more help than his struggling neighbours could give.

John Neilson, who had taken up a block north of Minimay Swamp, confirmed that the selectors could 'muster at least twenty (20) children'. Neilson had not then been to school himself, and the hand that pushed the pen was more accustomed to grasping an axe handle; but his sentences were clear and confident. The selectors used terms of gentility and formality as they 'begged respectfully' for attention; but at a time when few children in the world were educated by the 
state, they did not doubt that they had the right to ask the government to give them a school. The government agreed that the selectors' case was sound, and said that something would be done when funds were not so tight.

In 1883 the government reserved five acres for a school on the northwest edge of Minimay Swamp. A year later when a public works officer inspected the site he reported that this was one case where the surveyors had done what they were often accused of doing: they had chosen 'the worst site they could find'. There was no house in sight, not even a fence, the land was low-lying, and it was cratered and warped with crab-holes. Workmen, trying to unload a portable school from a bullock wagon, had to take their boots off and wade through water. They cut timber to keep the dismantled school above flood level. The Minimay parents petitioned the Minister to shift the school to a new site on a dry bank half a mile to the east. In the face of the righteous indignation of the selectors, the district school inspector wondered why local people had not previously pointed out that the site was unusable for half the year. He agreed that the school, one classroom and two small rooms for the teacher's quarters, be erected at the new site.

When the selectors first asked for a school they were uncertain what name it should be given. For a while they assumed that their school would be Lemon Springs, but in 1885 the Education Department designated the new building, Minimay School No.2600. The next year another school about six miles to the east was given the name, Lemon Springs. Soon there was a Minimay store and wine bar, a post office and a sportsground. The schools were important in defining communities, and fixing their centres.

Minimay had a building, but no teacher. John Neilson, who had already written twice to point out that there were 'a number of children here that [would] soon be beyond school age', wrote again to ask why there was no teacher. He was right to worry; the nine-year-olds had turned fourteen between the time the selectors made their first request, and the opening of the school.

After several teachers refused appointment to Minimay, the Education Department sent nineteen-year-old Norman McLeod to open the school. McLeod had not been to teachers' college, but he had served four years as a student teacher at Beaufort in western Victoria. He arrived by coach at Minimay on 6 May 1885 and opened the school; and he began work without 'the necessary furniture' of a blackboard and a teacher's desk. McLeod left Minimay three months later suffering, the examining doctor said, from pains in the chest and general debility 'brought on by work and want of proper food'. The school stayed shut, and the children were left to work or roam. 
Again the selectors wrote their letters of complaint: 'the children [were] going back daily'. A relieving teacher, James Groutsch, arrived after a month, stayed two months, and was replaced by Donald Schultz. Within a few weeks of the start of 1886 Schultz was posted to Tallengower. Groutsch hired a buggy at Department expense and came back briefly until Margaret Brennan took over. But Brennan, home with her mother over Christmas, died suddenly; she had no will and no assets but for the few pounds still owing from her annual salary of $\$ 128$ plus results. The staff changes continued. Groutsch made a third brief appearance before the children of Minimay. In the first three months of the school's existence the relieving teacher spent more time in the Minimay classroom than any of the other seven head teachers.

The Minimay parents, sick of the traffic in head teachers, held a meeting and E. Jelbart wrote to the Secretary of the Education Department saying that they wanted a permanent male teacher. The Department, constricted by its own regulations, continued to appoint according to the staff lists, and its instructions to teachers to go to Minimay 'without delay' were met with letters of anguish and inventiveness. Annie Forbes said she had made careful enquiries and had learnt on reliable authority that the school was near a tract of swamp. She was sure 'were I to go there, that my health would break down in a very short time ... owing to the constitutional weakness of the chest and throat'. Also, she wrote, she was supporting her aged mother. W.B. Newton, already serving in the Mallee, said that his health was 'undermined by want of a proper diet' and as he was trying to do further study he 'would like somewhere nearer civilization'. Miss S. Halligan wrote from her isolated school at the mining town of Walhalla in Gippsland:

I beg most respectfully to point out that the school is situated in a most extremely wild and remote district, and my friends contest it is utterly unfit for the residence of an unmarried female who would have to live entirely alone.

The Department accepted the pleading of most of its teachers: few suffered any penalty on the promotions list.

Miss Mary Dennis, certain that she would suffer 'hysteria' from loneliness in such a distant part of the colony, made an extra plea for sympathy by pointing out that she was an orphan. When Jelbart wrote her a soothing letter about Minimay and told her of the 'respectable family' with whom she could board, Dennis wrote to ask the Department if the offer was still open. The fact that she was an orphan then became a reason why she was 'eager to get on'. She took up duty at Minimay on 24 October 1887 and left at the end of the year. 
Miss Isabella Strachan applied to be sent to the Minimay area; but soon after she complained about the place and her lodgings. Rose Jelbart, who had taken Strachan into her home, suppressed her hurt, and made a strong reply. It was true, Mrs Jelbart wrote, that Miss Strachan had to share a room with a girl paid to work in the house, but she was 'treated more like a daughter than a servant. I would not think', Mrs Jelbart said, 'of putting anyone in a room with a lady teacher that was not thoroughly respectable and very well behaved'. If Miss Strachan insisted, then Mrs Jelbart would at great inconvenience remove her own sister from her room and give that to Miss Strachan, 'for our school is our great anxiety, and we always try to make teachers comfortable'. Mrs Jelbart ended her defence of her hospitality: 'The best way I can put it is - we make them one of our family'. It was not enough: Miss Strachan did not complete the year at Minimay.

In February 1889 Miss Sarah Bradley arrived to take over the school. The first teacher willing and able to stay more than twelve months, Miss Bradley was not to retire from the Education Department for another forty years. But in the two winters she taught at Minimay the floods came north, seeping, wind-blown and sometimes rushing into low land. Attendance dropped. In June 1890 the average attendance was seven, it was six in July, and five in August. Even in November there were still two families cut off from the school by swamps. The Department reduced the status of the school to 'temporary' and therefore Miss Bradley had to shift.

No teacher arrived at the start of 1891 and the parents renewed their protest against neglect. Then Edward Hayes arrived, he won the support of the community, the swamps dried, and the enrolment went to over twenty. The Department instructed Hayes to be ready to shift as the school was to be reclassified and he was not qualified to hold his position in a larger school. One group of parents objected: they were, they said, 'most unwilling to lose our teacher'. But other parents wanted their school returned to its old level; they thought that would be to their advantage in the long run. The school was re-classified, Hayes left, and numbers fell again. When the inspector arrived in mid-1893 there were only four children present, and the teacher thought that the monthly average would be only three. Minimay closed in September 1893. The parents enlisted the aid of a member of parliament, and Minimay was resurrected in 1894 as a half-time school with Lemon Springs. The teacher taught three days at Lemon Springs and two at Minimay. In 1901 Minimay again became a full-time school. It continued until 1951 when it was transported once, and the children daily, to become part of Goroke Consolidated School.

Besides the basic problem of getting both a teacher and enough pupils together in the one room, there were other and briefer disruptions to education in Minimay. Dependent on the one teacher, the school was always vulnerable 
to the vagaries of personal illness or family bereavement or any other of the random impediments likely to afflict someone trying to do a job. James Groutsch arrived by coach from Horsham on 20 January 1887, he opened the school, but no children came because they did not know that a teacher had turned up. Sarah Bradley missed a day in June 1889 because she lost the school key. The Department reluctantly accepted her explanation, and told her to be more careful in future. A Department officer also reprimanded Groutsch when he stayed home on a day of constant rain: wet weather and impassable roads were 'not sufficient reason for not opening the school'. Groutsch missed another day when he went to Goroke to celebrate Empire Day, broke a buggy pole on the way back, and could not reach Minimay in time for school the next day. Bradley's horse fell with her on the way to school; and the Department accepted her absence without comment.

The school's tin chimney with its lean to the east sometimes drew smoke upwards, and sometimes rolled it back into the classroom. The children escaped into the yard, dried their eyes, the teacher put the fire out, and the children eventually went back to a room that was 'horribly cold and cheerless'. The Departmental officer in Melbourne noted that as it was already August, the worst of the winter was over, and the repairs could wait. Early the next year the chimney was altered, but smoke still billowed into the classroom, and children were absent with sore eyes and colds.

The 1887 school year began with the children from six families gasping and racking with whooping cough. On some days no one went to school. At least it was not diphtheria. If the 'dip' struck a small school the teacher might have to write 'deceased' two, three or even four times in the right hand column of the Pupils' Register. When the school re-assembled a fifth of the spaces at the long forms could be empty.

The history of the Minimay school has much in common with other bush schools built on corners reserved from the lands of cockies and blockies. The small farmers, storekeepers and the local government officers such as policemen persisted until the Education Department agreed to provide a building; distant officials despatched blackboards, desks and 'notes of moral lessons', alphabet cards and a manual of drill; and a young man or woman arrived, reluctant, apprehensive or enthusiastic, to teach. Unlike a church the school belonged to everyone. Unlike a post office or a railway station which also provided a service, the school was taking some members of the community and trying to influence what they knew, what they did, and what they could become. Like Minimay, other schools of the area that started in the 1880s - Booroopki, Bringalbert North, Neuarpurr and Lemon Springs - were all at some time closed or reduced to half-time. The schools suffered when drought, floods or bad prices forced selectors off their blocks; and they suffered from the random effects of family 
sizes and teacher competence and stability. As in other early rural schools many children at Minimay were old for their grade. In 1890 one fourteen-year-old was in grade four. In grade three the children varied in age from eight to twelve.

Minimay was different from the other schools because of one pupil who went there. When John Neilson wrote repeatedly on behalf of those children passing from days of play to a lifetime of work before the district had a school, one child he had in mind was his own son, John Shaw Neilson. Before the Neilsons left Penola in South Australia and drove their wagon and cattle to the selection pegged at Minimay, Shaw Neilson had gone to school for about fifteen months in 1880 and 1881 . He was just over thirteen when the school opened at Minimay, and by the time he left the next year he had watched at least three teachers and Jas. Groutsch on a second stint - stand at the blackboard and easel in the narrow classroom, the sun a shaft of yellow air in the small north window. The only reading books in the school in Neilson's time were Thomas Nelson's Royal Readers; and perhaps just before he left there were three geography books, and wall maps of the World, Australasia and Victoria to be gazed at by the curious or dreamy or indolent. Shaw Neilson was remembered by one of the younger boys at Minimay as 'quiet ... spare and tough with that haggard look common among "grafting" bush boys'. He was a boy of no 'outstanding characteristics'; just another country kid in 'clodhopper boots', broad hat and pants at half-mast. He is known now by other Australians as one of the nation's finest poets, the singer of delicate songs. He began writing verse the same year that he left school.

Neilson, so sensitive to the music in words and to colour, could have taken little from the Minimay school. Groutsch who taught him for the longest was asked by the Department why he taught no singing or drawing. He explained simply: 'I am not skilled in drawing, and have no voice for singing'. The Royal Readers, dense volumes of over three hundred pages, provided the rhetoric and sentiment of empire: the Great Siege of Gibraltar, the Battle of Trafalgar and the Death of Nelson, the Balaclava Charge, and the Relief of Lucknow. But the Readers did contain the best known poems of Browning, Byron, Goldsmith, Scott, Shelley, Tennyson and Wordsworth.

Neilson's lack of schooling narrowed his art. He admitted: 'When a critic says ... that I have a very limited range of words, he is not far from the truth'. And sometimes his bush pronunciation led him into faulty rhythms. His evening became 'even-ing', and remembrance became 'remember-ance'. He accepted correction quietly. He was not a man of anger or excuses.

Most of Shaw Neilson's education was at home. His cheerful father, whose life was endless hard work and a cycle of debt and foreclosure, wrote verse and treasured his few books. He knew Adam Lindsay Gordon by sight, and his poetry in detail. Shaw Neilson's mother taught a 'hard, hard religion' of a God 
whose blue rage was always about to fall on the unwary. She cooked no meals on Sunday and left the cows to bellow as their udders swelled and milk oozed from their teats. But it was to his mother that he took his first verses. In 1889 the Neilson family, the parents and Shaw, the oldest of five children, crossed floods and the Little Desert to take up a rented farm four miles out of Nhill. It was a continuation of what was to be another thirty years of failed farms, contracting for bush jobs, and wage labour.

Late in life Shaw Neilson said that his poems came pressing into his head 'too thickly, like a lot of cabbages in a bed'. Another time he said they were like 'puppies all pushing and battling for their mother's teats'. Neilson lost many poems and part-poems; they were jostled from his mind by other ideas and rhythms before he could fix them in writing. He wrote his first published poems at fifteen or sixteen, before he left Minimay, and in his later poetry returned again and again to that land of red gum, stringybark, she-oak, creek and floodway. Minimay gave him his images of both wealth and poverty. He built his ideal land from fragments of good times and good years. It was a place where: 'The lakes shall be many and gentle'. A time when:

The oats they were over the fences, and seven feet high!

Our own little creek, it was flooded a dozen times over;

And water-birds came without warning to blacken the sky.

Neilson's good land was rich with wild honey and birds: cranes, plovers, wrens, mallee fowl, native companions and the smoker parrot with 'Moonlight and sunrise' running on its wing and 'Lightning and sundown, every joy in yellow' in its coat.

The 'poor, poor country' was there too. It was where 'the thin wheat and the brown oats were never two feet high'. It was where:

The land is all buckshot and sorrow,

It cries like a prayer;

The rubble it writes in the cutting-grass;

Famine is there.

When he wrote those lines he had in mind, he said, the iron-stone gravel country south of Minimay, patterned with stones forced up by the roots of the sword grass. In the poor country Neilson, the gentle dreamer, saw people made hard: 'Men with their dreams burning out' and 'wasting worn-out women too, 
Praying for death ...' Women who saw their children die, as Neilson's mother saw one of her sons die, turned in their anger and said that the 'God of love' was 'A foe to me and mine'.

Neilson was a 'homemade instrument'. His delicate craft owed most to his own abilities, the harsh and beautiful lands where he lived, and to his family, rather than to the weatherboard school. The succession of teachers that passed through Minimay probably had little idea of the talent being nurtured in thin, silent Shaw Neilson. But all teachers in one-teacher schools faced the possibility that on their own they might have to tend a talent able to speak to a world scarcely glimpsed in Royal Readers or on wall maps.

Other places, distinguished by a particular teacher or pupil, provide an equally good opening to an investigation of bush schools. In 1878 a nineteen-year-old Englishman was 'flung into the wide sea of Australian bush' to teach at the half-time schools of Sparkes Creek and Junction Creek in the Liverpool Range west of Scone in NSW. His name was Havelock Ellis. Later he was to write that 1878 was the 'loneliest, the most isolated' year of his life. It was also, he said, 'the most seminal and even the most ideal', 'the most fateful, the most decisive', 'that wonderful year', and 'the most eventful of my life'. In 1878 Ellis began writing serious prose, decided to study to be a doctor, 'gained health of body' and resolved the discord in his scientific and spiritual response to the world around him. Back in England and with his reputation established as one of the learned men in the arts and sciences, Ellis kept a photograph of Sparkes Creek beside his bed. Some of the teachers who stayed in the bush, starved of intellectual stimulation and tempted by farmers' nubile daughters, may have thought they knew why Havelock Ellis devoted so much of his life to writing his seven-volume Studies in the Psychology of Sex.

Bulby Brush public school on Bunya Creek in northern NSW was opened in 1920. All of the twenty-two families with children at the school were dairy farmers; two were share farmers and the rest were on their own or rented blocks. Bulby Brush was Standard Plan No 3; an eighteen-foot weatherboard square with big windows on the south, a verandah on the north and west, a tank stand on the shady southwest corner, and steps leading to the western verandah and the tiny 'hat room'. The interior was crowded with eight desks, each able to take four pupils. In 1935 Inspector D. Hayes said that a 'competent teacher' ought to be able to find 'satisfactory' accommodation for forty-five children. But in the following year the Department extended the school by seven feet and put in four more desks. Les Murray, born in 1938, went to Bulby Brush Standard Plan No 3 plus seven, and he saw it again as it is, and as he remembered it, when he drove to the nearby town of Gloucester:

... the pines round my one-teacher school 
With its zigzag air raid trench and morning flagpole;

From there I remember birthdays, and how to shin

Fast over fence rails: You're last! - I'll be first in Heaven!

At Pioneer in northeast Tasmania the rough board school with its shingle roof and ramshackle chimney was held nearly upright by poles bracing the walls. In 1906 the teacher was Joseph Lyons. Trained under the monitor system, he was soon to be one of the first teachers to enter the Hobart teachers' college. Lyons was to become premier of Tasmania in 1923 and prime minister of Australia in 1931. In the mid-1920s John Tonkin was the teacher at Group Settlement No. 6 in the extreme southwest of Western Australia. Big timber towered over the corrugated iron roof and in winter water lapped at the stumps of the school and the tank stand. John Tonkin became premier of his state in 1971. In Gippsland, Victoria, at the Tarraville school, easily mistaken for a church with its brick walls, high ceiling and vestry entry, Ada Crossley did her lessons. But it was her singing which took her to Melbourne, then overseas, and to command performances before her Queen. Her voice had an extraordinary purity and the luscious richness of a Carlsbad plum'.

In 1914 the Commonwealth Government asked the South Australian Education Department to supply a teacher to open the first government school in Alice Springs. A Commonwealth official wrote on the file: it was 'no place for an unprotected young woman'. The South Australian Department appointed Mrs Ida Standley. She went north by train to Oodnadatta, and the police were given the task of escorting her over the 600-kilometre track to Alice Springs. She retired as teacher to the white children and teacher and matron to the mixedrace children fifteen years later at age sixty. She is one of the few, perhaps only, bush school mistress to have her name on the map of Australia: Standley Chasm in the MacDonnell Ranges is named after her.

It is no surprise that distinguished Australians learnt and taught in the rural schools. After all, when the one-teacher schools were at their most numerous in the 1930s there were over 6000 of them. Over half were in New South Wales and Victoria and there were four in the Northern Territory. Assuming an average enrolment of twenty, then over 120,000 Australians were in one-teacher schools.

Small rural schools were common elsewhere in the world. What made the Australian system different was that the schools were part of highly centralized systems, the state met nearly all costs, in any one year some of the best young teachers were posted to distant country schools, and the number of children needed before the government provided a school was low. In South Australia 
just six children were enough to keep a school open. In the berry and apple growing valleys of Tasmania there was a school every four miles or so, and children walked to school.

A study of one-teacher schools opens many tracks into Australian history. The teachers can be seen as coming out of one community or sub-culture, going to an institution and then travelling to another community with the specific task of training the young. Under the pupil-teacher or monitor systems some teachers may not have been to any training college. Unlike teachers at large schools who had numerous colleagues and could select a particular group to mix with after school, the bush schoolies were in direct and constant contact with the community they served. A young woman who went into a dairying district in the 1930s might well be trapped in that community. Her board would be provided by a family tied to seven days a week of hard work. The only time members of the family could get away from the farm was in the middle of the day. The teacher might go for over a month before she could get to a bank and cash a cheque. Even the bicycle, the young teacher's means to independence, was of little value on wet hills and roads of black mud cut hock-deep at cattle crossings.

Seen as the setting for thousands of rural schools, Australian geography and social history become diverse. All teachers in training were aware of the dramatic differences between the suburbs of Brisbane and the islands of Torres Strait, or between an Italian cane-growing community near Tully and a centre on the Darling Downs dominated by the descendants of German settlers, or between the Huon Valley and the Bass Strait Islands. And practising teachers were quickly aware of other differences: the style and frequency of entertainment varied, expectations about the school differed, and the sense of cohesion and easy familiarity within communities changed markedly from one district to another. Teachers in their writings and memories are able to comment on many ordinary homes with the hessian walls recently whitewashed, and the wash basin carefully placed for the visitor; and they are able to say a lot about the communities that came together at the school Christmas concert.

At some schools all children came from similar homes. Out of the first sixty entries on the pupils' register for Minimay school kept from 1904 all parents are listed as farmers except three: a grazier, a farmer and grazier, and one home duties. But at Wee Jasper in the 1930s the list of occupations covered the full range of rural occupations: grazier, station manager, boundary rider, policeman, storekeeper, teacher, dingo trapper, road worker and simply 'dole'. All the children from those diverse homes met in the one small classroom, were taught by the same teacher and played under the giant gums on the bank of the Goodradigbee. How they acted towards each other, and what that schooling in common did to them should tell us much about wealth, behaviour and attitudes in Australia. 
Some women recall their bush school with delight: the one time in their lives of uncomplicated equality between the sexes. Others have less glowing memories. Several have said that in the playground the boys dominated. The biggest boys decided what game they would play and whether or not the rest of the school was needed. If the boys wanted to have a football match, one woman recalls, then it would be her job to be boundary umpire. She was not, however, allowed to say when the ball crossed the line. That was a decision for the boys who were playing. Her task was merely to retrieve the ball when told. With small numbers, the character of a school could change quickly. Cliff Green says that at one stage at Wilton all the older children were girls and they ran an efficient matriarchy.

The various education departments provided an incidental gene exchange. Men took wives from rural districts and young women married into the communities where they taught. From 1926 until the neighbouring schools at Kapinnie and Brimpton Lakes on the Eyre Peninsula of South Australia closed, eight women teachers married and settled in the area, and two women left as teachers' wives. Throughout Australia women ex-teachers became presidents and secretaries of the CWA and the hospital auxiliary; and their children were likely to go on to higher education.

The woman teacher fresh from the city was assessed by all the single young men; and with different intent and equal intensity she was inspected by the young girls sitting in the desks. The teacher's clothes, manners and her escape in the holidays to distant places made her much more like the women of the magazines. There was an unfair comparison with the mums who did the milking in bran bag aprons. The teachers by their very appearance beckoned bright and ambitious girls; and the school and a scholarship was one means to escape the narrow life on the farm. Shaw Neilson's sister, Maggie, took a job as part-time sewing mistress, and tried desperately to become a teacher by correspondence studies. Her nervous intensity drained away her cleverness, and she failed.

In 1910 W.H. Smith BA (Lond), the inspector for southwest Queensland, travelled over 11,000 miles by train, coach, buggy, sulky and motor car to visit all but two of the 115 schools in his district. Just the physical problems of surveillance in a centralized system covering such vast areas were immense. The inspectors' reports, with their comments on the trivial and the fundamental, are records of what mattered to the senior men and the centres of the state systems. The change over time in the inspectors' concerns and vocabulary are marked. In 1929 an inspector at Stradbroke in Gippsland wrote: 'The young children's lead pencils are not long enough. Much of the blotting paper should be destroyed; much untidy work is due to dirty used-up blotting paper'. In 1970 a successor wrote: Attempts to create an appropriate social \& emotional climate 
are being quite successful. Firm, positive relationships are being established'. An authoritarian interest in the insignificant had been replaced by a guess at the fashionable and intangible.

The punishment books are one record of what happened in the classroom and the playground. Successive entries from a NSW school in 1923 say something about the teacher's attitude to those who carried out crimes and those who benefited from them: 'stealing biscuits', two strokes with a cane; 'receiving biscuits', one stroke. And there is an ambiguity in the delinquency of a boy aged nine: 'Kissing a girl after two warnings', one stroke. The reasons why pupils were punished changed from general deficiencies such as 'gross laziness', 'idleness', and errors in classwork to specific crimes such as 'kicking a girl and lying', to no corporal punishment. To the 1940s girls were caned infrequently; after that their punishments were rarely corporal, and their crimes went unrecorded.

Inspectors' reports and the pupil registers document the changing function of the bush school. In 1910 most pupils in the one-teacher schools had all their formal education in that one school, and not many were reaching the eighth grade. Inspector Smith in southwest Queensland noted that only two per cent of scholars were in grade six and nine per cent in grades five and six. There should have been a total of thirty per cent in grades five and six. At Minimay about half the children enrolled between 1904 and 1920 completed eighth grade and gained their Merit certificate, and only two, both girls, were said to be going to high school. A teacher remembering his time at Kiamal north of Ouyen in Victoria, said, 'the Merit was the BA of the Mallee'. But by the 1940s it was very rare for a pupil to leave Minimay for immediate 'home duties' or 'farm work'; nearly all were going on to high or technical school.

Most of the one-teacher schools were utilitarian rectangles of weatherboard under a corrugated iron roof. Early in South Australia galvanized iron walls were also common, and chapel-like stone schools were built in the Adelaide hills and beyond. The granite schools at Faraday, Sutton Grange and elsewhere in central Victoria made good use of the local quarries and local skills. The scholars at Boonmoo in north Queensland began work in July 1910 in one of several 'tent schools' then in use. The iron sides were five or six feet high, then calico continued over the wall plates and across to form a ceiling below the iron roof. There were no windows and 'the heat was intolerable'. Railway carriages were used as classrooms at work camps, and indigent governments sometimes hired community halls or other buildings. Between the wars Bob Allanby taught at a school housed in a surviving section of the Port Arthur convict settlement. The thousands of tourists who now tramp though the stone building are told of only its first public function. 
What went on in particular buildings is worth knowing because it can make a page, perhaps more, in biographies. But general research into the experiences of those who taught and those who learnt in the one-teacher schools is important for the access it gives to a distinct part of Australian educational history, and to what went on in many rural communities. Two final observations. Where once the basic groups among parents were based on race, nationality, religion, wealth and pretensions to position, by 1970 some rural communities were divided between old farmers and timber workers on one side and alternative life-stylers on the other. In 1930 children got themselves to school; in 1980 their parents drove them in the car - or the four-wheel drive. 
This text taken from The Boy from Boort: Remembering Hank Nelson, Edited by Bill Gammage, Brij V. Lal, Gavan Daws, published 2014 by ANU Press, The Australian National University, Canberra, Australia. 